\title{
PENERAPAN METODE LEARNING PARTNER UNTUK MENINGKATKANKEMAMPUAN PERHITUNGAN PECAHAN PADA SISWA KELAS V SDN 46 LELA KOTA BIMA
}

\author{
Muhammad Yamin, Syarifuddin, Muh. Fitrah \\ IAI Muhammadiyah Bima, Indonesia \\ Email:muhammad@gmail.com, syarifpps@gmail.com, \\ fitrahmath@gmail.com
}

\begin{abstract}
Abstrak:
Penelitian ini bertujuan untuk mengetahui kemampuan perhitungan pecahan siswa kelas V SDN 46 Lela Kota Bima melalui penerapan metode learning partner. Jenis penelitian ini adalah PTK, dengan subjek peneliti siswa kelas V SDN 46 Lela Kota yang berjumlah 28 siswa terdiri dari 16 siswa laki-laki dan 12 siswa perempuan. Metode pengumpulan data yang digunakan dalam penelitian ini terdiri dari observasi, wawancara, dokumentasi dan tes kemampuan perhitungan pecahan. Hasil penelitian menunjukan bahwa pembelajaran Matematika menggunakan metode learning partner dapat meningkatkan kemampuan perhitungan pecahan siswa kelas V SDN 46 Lela Kota Bima. Hal ini ditunjukkan dengan terjadinya peningkatan skor rata-rata dari siklus I yakni 58.57 kemudian meningkat sangat signifikan pada siklus II yakni menjadi 85,71. Sedangkan pencapaian ketuntas belajar pada siklus I sebesar 17,9\% dan meningkat pada siklus II yakni sebesar 92,9\%. Selain itu, aktivitas atau sikap siswa saat penerapan metode pembelajaran learning partner dalam pembelajaran matematika materi perhitungan pecahan pada siklus I ratarata persentase keseluruhan aktivitas positif siswa pertemuan pertama sebesar 38,93\% dan aktivitas negatif sebesar 61,07\%. Namun, pada pertemuan kedua, aktivitas positif siswa meningkat menjadi $55,36 \%$ dan aktivitas negatif pada saat pembelajaran berlangsung menurun menjadi $44,64 \%$. Sedangkan pada siklus II pertemuan pertama sebesar $81,43 \%$ dan aktivitas negatif sebesar $18,57 \%$. Namun, pada pertemuan kedua, aktivitas positif siswa meningkat menjadi $94,29 \%$ dan aktivitas negatif pada saat pembelajaran berlangsung menurun menjadi 5,71\%.
\end{abstract}

Kata Kunci: Metode Learning Partner, Kemampuan Perhitungan Pecahan.

\section{PENDAHULUAN}

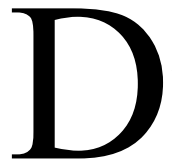

alam pelajaran matematika terdapat berbagai materi yang harus di berikan pada siswa dari sekian banyak yang di berikan, adalalah satu materi yang di anggap siswa sangat sulit yaitu mengenai operasi perhitungan pecahan. Di dalam menghitung pecahan, siswa pada SDN 46 Lela Kota Bima mengalami banyak kesulitan. hal ini terlihat dari hasil ulangan harian yaitu $50 \%$ siswa mendapat nilai di atas 75 dan $50 \%$ siswa belum mencapai kliterial ketutuntasan minimal (KKM) adapum KKM yang di tetapkan yaitu 75 . Kurangnya kemampuan menghitung demikian tentu saja banyak penyebabnya, antara lain karena siswa kurang tertarik pada mata 
pelajaran matematika terutama mengenai operasi perhitungan pecahan sebab materinya sangat sulit. Mungkin juga karena kurangnya penggunaan media dalam penyampaian materi operasi hitung pecahan oleh guru.

Berdasarkan hasil obesrvasi awal pada tanggal 06 April 2021 di SDN 46 Lela Kota Bima diperoleh data berupa nilai rata-rata ulangan harian mata pelajaran matetamtika siswa kelas V semester genap tahun ajaran 2021/2022 ditemukan banyak siswa belum mencapai nilai Kriteria Ketuntasan Minimal (KKM) pada mata pelajaran matematika dengan materi pecahan. Bersumber dari data di atas, terdapat 28 siswa kelas $\mathrm{V}$, hanya 12 siswa yang memperoleh nilai 70 ke atas atau sekitar $(42,86 \%)$ dan 16 siswa yang memperoleh nilai 69 ke bawah atau sekitar $(57,14 \%)$. Adapun nilai rata-rata ulangan harian siswa kelas V SDN 46 Lela Kota Bima secara keseluruhan adalah 65,71 dengan nilai terendah 45 dan nilai tertinggi 80 . Rendahnya kemampuan siswa dalam mengerjakan soal pecahan berdampak pada rendahnya pencapaian Kriteria Ketuntasan Maksimal (KKM) sebesar 75, karena menguasai operasi hitung perkalian pecahan terutama pada SD memberikan kontribusi besar pada tercapainya KKM.

Siswa dalam mempelajari operasi hitung bilangan pecahan masih nampak kurang mampu misalnya pada kelas $\mathrm{V}$ para siswa mulai mengoperasikan perkalian dan pembagian, dalam operasi ini para siswa mengalami hambatan karena belum mampu menguasai operasi hitung pecahan. Kemampuan menghitung pecahan yang rendah membuat kita prihatin, mengingat begitu pentingnya peranan menghitung pecahan dalam kehidupan siswa. Untuk mengatasi masalah di atas, guru perlu menerapkan berbagai metode yang sesuai dengan materi luas permukaan bangun ruang agar siswa tidak hanya mengikuti pembelajaran secara pasif melainkan siswa juga terlibat aktif dalam pembelajaran. Dalam pembelajaran, guru juga tidak sekedar memberikan materi pembelajaran tetapi juga sebagai motivator yaitu guru harus berusaha membuat siswa terdorong dan tertarik akan materi pembelajaran matematika. Siswa perlu diberikan dorongan atau rangsangan agar tumbuh motivasi pada dirinya untuk belajar. Dengan demikian, guru harus memilih metode yang tepat agar dapat mengatasi masalah tersebut. Salah satu metode mengajar yang mempunyai cara belajar siswa aktif dan kreatif adalah metode pembelajaran belajar mitra (learning partner).

Metode pembelajaran learning patners biasa disebut dengan mitra-mitra belajar adalah suatu pembelajaran kooperatif yang dibentuk dalam kelompokkelompok kecil. Terdapat empat tahapan keterampilan yang harus ada dalam metode learning partners yaitu: 1) Forming (pembentukan); 2) 
Functioniong (pengaturan); 3) Formating (perumusan); 4) Fermenting (penyerapan). Patners in learning juga bisa disebut suatu proses kerja sama yang dilakukan oleh baik antar individu maupun antar kelompok, yang saling penuh perhatian dan penghargaan sesama anggota untuk mencapai tujuan bersama (Kusumaningsih, 2015: 7). Belajar mitra (learning partner) adalah cara tukar pikiran antara dua orang atau lebih, dalam kelompok-kelompok kecil, yang direncanakan untuk mencapai tujuan tertentu. Learning partner juga bisa disebut suatu proses kerja sama yang dilakukan oleh baik antar individu maupun antar kelompok, yang saling penuh perhatian dan penghargaan sesama anggota untuk mencapai tujuan bersama (Hajar, 2020: 67).

Metode belajar mitra memiliki kelebihan-kelebihannya tersendiri, antara lain (1) Meningkatkan kerja sama antar siswa. (2) Tutor teman sebaya. (3) Dapat dibantu belajar melalui bantuan rekan. Dan menjadikan seseorang atau beberapa orang siswa yang ditunjuk oleh guru sebagai pembantu guru dalam melakukan bimbingan terhadap kawan sekelas. Seseorang yang memiliki kemampuan pengetahuan dan nilai prestasi belajar yang lebih besar dari kawannya. (4) Meningkatkan pemahaman atas konsep dan atau proses pembelajaran. (5) Melatih siswa berkomunikasi dengan baik dengan teman sebangkunya. Metode pembelajaran belajar mitra (learning patners) ini dilaksanakan dengan membagi siswa menjadi berpasangan untuk mengerjakan suatu tugas dari guru. Kegiatan pembelajaran seperti ini mampu membantu siswa dalam mengungkapkan kembali konsep-konsep materi yang telah dipelajari sehingga menyebabkan penguasaan siswa terhadap materi dapat meningkat dan mengakibatkan hasil belajar matematika khususnya materi pecahan dapat meningkat dan lebih optimal.

Selain itu, tujuan digunakan metode mitra perhitungan pecahan adalah untuk memudahkan siswa dalam menangkap dan memahami materi khususnya menghitung pecahan. Berdasarkan hal tersebut metode pembelajaran mitra sebagai metode yang sangat penting dalam menunjang kelancaran pelaksanaan pembelajaran dalam meningkatkan kemampuan menghitung pecahan siswa. Berdasarkan latar belakang permasalahan di atas, maka arah penelitian ini dimaksudkan untuk mendeskripsikan rumusan masalah dalam peneliti ini, mencakup: 1) bagaimanakah penerapan metode belajar mitra dapat mencapai ketuntasan belajar matematika materi perhitungan pecahan pada siswa kelas $\mathrm{V}$ SDN 46 Lela Kota Bima Tahun Ajaran 2021, dan 2) apakah penerapan metode belajar mitra dapat meningkatkan kemampuan perhitungan pecahan pada siswa kelas V SDN 46 Lela Kota Bima tahun ajaran 2021. 


\section{METODE PENELITIAN}

Penelitian ini menggunakan jenis penelitian tindakan Kelas (PTK). Penelitian Tindakan Kelas adalah suatu bentuk reflektif dan kolektif yang dilakukan oleh peneliti dalam situasi sosial untuk meningkatkan penalaran praktek sosial mereka (Sanjaya, 2010). Menurut Suyadi "Penelitian Tindakan Kelas adalah perencanaan dalam bentuk tindakan terhadap kegiatan belajar yang sengaja dimunculkan dan terjadi dalam sebuah kelas secara bersamaan". (Suyadi, 2013). Penelitian tindakan kelas merupakan suatu bentuk kajian yang bersifat reflektif oleh pelaku tindakan, yang dilakukan untuk meningkatkan kemantapan rasional dan tindakan mereka dalam melaksanakan tugas, memperdalam pemahaman terhadap tindakan yang dilakukannya, serta memperbaiki kondisi dimana praktek pembelajaran tersebut dilakukan.

Penelitian tindakan kelas ini telah dilaksanakan mulai bulan Juli sampai dengan Agustus tahun 2021 yang berlokasi di SDN 46 Lela Kota Bima pada siswa kelas V. Teknik pengumpulan data yang digunakan pada penelitian ini adalah hasil pengamatan lembar observasi, wawancara dan tes kemampuan perhitungan pecahan. Teknik analisis data yang digunakan adalah statistik deskripsi dan tes ketuntutasan hasil belajar. Statistik deskriptif adalah statistik yang berfungsi untuk mendeskripsikan karakteristik dari objek yang diteliti yang terdiri dari skor rata-rata, median, standar deviasi, tabel frekuensi, nilai minimum dan nilai maksimum yang diperoleh siswa pada setiap akhir siklus. Sedangkan teknik kuantitatif dipakai untuk menganalisis hasil tes subjektif siswa yang dilakukan pada setiap siklus. Nilai siswa pada setiap akhir siklus dijumlahkan kemudian dihitung dalam presentase.

\section{HASIL DAN PEMBAHASAN}

Metode pembelajaran learning patners biasa disebut dengan mitra-mitra belajar adalah suatu pembelajaran kooperatif yang dibentuk dalam kelompokkelompok kecil. Patners in learning juga bisa disebut suatu proses kerja sama yang dilakukan oleh baik antar individu maupun antar kelompok, yang saling penuh perhatian dan penghargaan sesama anggota untuk mencapai tujuan bersama (Kusumaningsih, 2015: 7). Metode pembelajaran belajar mitra ini akan dilaksanakan dengan membagi siswa menjadi berpasangan untuk mengerjakan suatu tugas dari guru. Kegiatan pembelajaran seperti ini mampu membantu siswa dalam mengungkapkan kembali konsep-konsep materi yang telah dipelajari sehingga menyebabkan penguasaan siswa terhadap materi dapat meningkat dan mengakibatkan hasil belajar matematika khususnya materi pecahan dapat meningkat dan lebih optimal. Selain itu, tujuan digunakan metode mitra perhitungan pecahan adalah untuk memudahkan siswa dalam 
menangkap dan memahami materi khususnya menghitung pecahan. Berdasarkan hal tersebut metode pembelajaran mitra sebagai metode yang sangat penting dalam menunjang kelancaran pelaksanaan pembelajaran dalam meningkatkan kemampuan menghitung pecahan siswa.

Dalam pelaksanaan model pembelajaran leraning patners menuntut siswa untuk memecahkan masalahnya secara mandiri dengan berdiskusi antar pasangan, dengan mengadakan pertukaran antar anggota kemompok dimana setiap anggota kelompok diberi tugas untuk menjelaskan hasil diskusinya kepada kelompok lain dan kemudian saling bertukar pendapat sehingga setiap anggota kelompok diharuskan memahami dan menguasai hasil diskusi yang telah mereka kerjakan (Aprianika, 2019: 101).

Berdasarkan hasil penelitian yang terdiri aktivitas siswa, guru/peneliti dan hasil belajar kemampuan perhitungan pecahan siswa kelas V SDN 46 Lela Kota Bima melalui dua siklus dengan menggunakan metode pembelajaran learning patners telah mengalami peningkatan yang sangat signifikan. Pada hasil tindakan siklus I pada dasarnya belum tercapai apa yang diharapkan. Pada tahap pertama dalam melaksanakan pembelajaran, siswa belum sepenuhnya melaksanakan indikator yang terdapat pada rencana pembelajaran yang telah disiapkan dan disusun oleh peneliti. Hal ini membuktikan bahwa masih terdapat siswa yang kurang aktif dalam menjawab sola LKS, kurang teliti dalam menjawab soal, penggunaan waktu yang kurang efisien, serta masih di dapati siswa malu-malu dalam mengemukakan pendapatnya pada saat melakukan tanya jawab. Sehingga dapat dibuktikan bahwa siswa belum sepenuhnya memahami materi yang disampaikan.

Hasil analisis deskriktif menunjukkan bahwa kemampuan perhitungan pecahan pada siswa kelas V SDN 46 Lela Kota Bima melalui metode learning patners diperoleh nilai rata-rata pada siklus I yaitu 58.57 dari skor ideal yang ingin dicapai yaitu 100. Siswa yang memperoleh ketuntusan belajar dari 28 siswa pada siklus I yaitu hanya 5 orang siswa (17,9\%), sedangkan sebanyak 23 orang siswa $(82,1 \%)$ tidak tuntas dalam belajarnya. Dari segi ketuntasan hasil belajar siswa secara klasikal pada siklus I menunjukkan belum tuntas atau berada pada kategori kurang. Masih adanya siswa yang memperoleh nilai dibawah nilai rata-rata KKM yakni 75 dan berada pada kategori cukup. Keadaan tersebut disebabkan masih ada siswa yang kurang memperhatikan penjelasan dari peneliti, berbicara dengan temannya, dan kesulitan dalam menjawab soal pecahan, karena terkadang ada siswa yang masih gaduh, sehingga menyebabkan siswa kurang memahami ataupun lupa tentang materi yang disampaikan. 
Berdasarkan hasil analisis data pada siklus II menunjukan bahwa secara klasikal pada siklus II telah tuntas atau kategori baik dan baik sekali. Pada siklus II terjadi peningkatan rata-rata kemampuan perhitungan pecahan siswa kelas V SDN 46 Lela Kota Bima yang diperoleh pada siklus I yaitu 58.57 dan meningkat pada siklus II menjadi 85.71. Ditinjau dari segi ketuntasan individu juga terjadi peningkatan pada siklus I berjumlah 21 siswa dan pada siklus II meningkat secara signifikan menjadi 26 siswa. Dengan demikian secara klasikal pada siklus II telah tuntas dibandingkan dengan siklus I. Peningkatan kemampuan perhitungan pecahan dengan menggunakan metode learning patners pada siswa kelas V SDN 46 Lela Kota Bima disebabkan oleh adanya perbaikan-perbaikan yang dilakukan oleh guru dan peneliti saat proses penelitian. Dengan adanya peningkatan nilai rata-rata tiap siklus membuktikan bahwa pembelajaran Matematika materi perhitungan pecahan melalui metode pembelajaran learning patners dapat memotivasi siswa dan akhirnya berpengaruh terhadap kemampuan perhitungan pecahan. Menurut Rosni Yenti, model pembelajaran kooperatif dengan teknik bertukar pasangan merupakan solusi yang peneliti ambil untuk meningkatkan hasil belajar siswa SD, Karena model pembelajaran kooperatif teknik bertukar pasangan dalam penerapannya akan membuat suasana kelas menjadi lebih aktif dan membuat siswa berusaha menemukan jawaban suatu masalah pada sebuah materi dengan sedirinya. Aktivitas dikelas yang seperti ini akan meningkatkan kembali hasil belajar siswa (Yenti, 2018: 968).

Berdasarkan hasil observasi pada siklus I diketahui bahwa dalam proses pembelajaran Matematika materi perhitungan pecahan melalui metode pembelajaran learning patners terlihat masih ditemukan siswa yang berperilaku negatif seperti tidak mendengarkan dan memperhatikan guru ketika mengabsen, tidak memperhatikan peneliti saat menjelaskan prosedur kegiatan siswa dan mengerjakan LKS, dan tidak mempresentasikan hasil diskusi sesuai dengan format yang ada pada LKS. Perilaku negatif yang dilakukan siswa tersebut disebabkan oleh beberapa faktor diantaranya siswa kurang mengetahui pentingnya keterampilan perhitungan pecahan dan hal ini berdampak pada kurangnya minat dan motivasi siswa dalam mengikuti pembelajaran Matematika khususnya materi perhitungan pecahan. Untuk mengatasinya peneliti berusaha memotivasi siswa dengan menanamkan pada siswa bahwa materi perhitungan pecahan merupakan keterampilan yang sangat penting dan mendasar yang dapat berpengaruh terhadap pemahaman terhadap mata pelajaran Matematika. Adapun skor persentase keseluruhan aktivitas positif siswa saat pembelajaran pada pertemuan pertama sebesar $38,93 \%$ dan aktivitas negatif sebesar $61,07 \%$. Namun, pada pertemuan kedua, aktivitas positif siswa 
meningkat menjadi $55,36 \%$ dan aktivitas negatif pada saat pembelajaran berlangsung menurun menjadi 44,64\%. Hal ini menunjukan bahwa pada siklus I rata-rata persentase keaktifan siswa belum optimal atau belum mencapai kriteria keberhasilan yang ditetapkan yaitu $80 \%$ karena rata-rata persentase keaktifan siswa pada siklus I maksimal 55,36\%.

Hasil observasi siklus II diketahui bahwa aktivitas siswa saat pembelajaran berlangsung pada siklus II baik pertemuan pertama dan pertemuan kedua, maka dapat diketahui bahwa skor persentase keseluruhan aktivitas positif siswa saat pembelajaran pada pertemuan pertama sebesar $81,43 \%$ dan aktivitas negatif sebesar 18,57\%. Namun, pada pertemuan kedua, aktivitas positif siswa meningkat menjadi $94,29 \%$ dan aktivitas negatif pada saat pembelajaran berlangsung menurun menjadi $5,71 \%$. Hal ini menunjukan bahwa pada siklus II rata-rata persentase keaktifan siswa sudah optimal atau sudah mencapai kriteria keberhasilan yang ditetapkan yaitu $80 \%$ karena rata-rata persentase keaktifan siswa pada siklus II maksimal sebesar 94,29\%. Menurut Merti Selan, dkk menyatakan bahwa model pembelajaran berpasang-pasangan merupakan salah satu model dalam strategi pembelajaran aktif, yakni strategi dimana merangsang agar siswa menjadi lebih aktif dan dapat mengubah kebiasan belajar berpusat pada guru menjadi terpusat pada siswa sehingga dapat mengefektifkan proses belajar kelompok kemudian menumbuhkan suasana kreatif dan menyenangkan serta membuat siswa trampil mengerjakan soal-soal dan belajar mengatasi masalah (Selan, 2018: 151).

Berdasarkan serangkaian analisis data dan situasi pembelajaran yang telah dijelaskan di atas bahwa perilaku siswa dalam pembelajaran mengarah pada perilaku positif yaitu siswa semakin aktif dan lebih bersemangat. Suasana belajarpun berubah menjadi lebih aktif dan lebih hidup dengan kegiatan mengamati, mengeksplorasi dan berinteraksi serta memahami. Dengan demikian, dapat disimpulkan bahwa belajar Matematika materi perhitungan pecahan dengan menggunakan metode pembelajaran learning patners adalah sangat baik, karena dapat membantu siswa dalam mengalami kesulitan dalam pembelajaran khususnya kemampuan perhitungan pecahan dan memberikan pengetahuan yang lebih kepada siswa karena adanya upaya dari diri siswa untuk memecahkan suatu masalah dalam belajar khususnya Pelajaran Matematika. Siswa pun menjadi lebih termotivasi untuk lebih giat dalam belajar sehingga akan berdampak pada peningkatan kemampuan menulis puisi. Dengan demikian telah menjawab hipotesis yang telah dirumuskan sebelumnya yang menyatakan "Jika metode learning partner diterapkan, maka kemampuan perhitungan pecahan siswa kelas V SDN 46 Lela Kota Bima akan meningkat. Dengan demikian hipotesisi dalam penelitian ini diterima. Hal yang terpenting 
sebelum melakukan kegiatan pembelajaran yaitu guru terlebih dahulu harus menentukan model pembelajaran mana yang baik dan cocok dengan materi yang akan disampaikan. Sehingga tujuan pembelajaran yang di inginkan dapat tercapai.Dengan begitu guru tidak hanya dituntut untuk menguasai materi saja melainkan juga dapat mempratekannya dikelas sesuai dengan model pembelajaran yang digunakan (Wulandari, 2013: 12). Hasil penelitian yang dilakukan oleh Rahmi Zulva bahwa pengaruh dari metode belajar mitra dalam pembelajaran yang diterapkan kepada peserta didik lebih tinggi dibandingkan dengan metode ceramah. Ini dapat dikatakan pembelajaran menggunakan metode belajar mitra ini lebih efektif dalam meningkatkan hasil belajar dan berpengaruh terhadap hasil belajar siswa (Zulva, 2020: 23).

\section{SIMPULAN}

Terjadi perubahan aktivitas atau sikap siswa saat penerapan metode pembelajaran learning patners dalam pembelajaran matematika materi perhitungan pecahan pada siklus I rata-rata persentase keseluruhan aktivitas positif siswa pertemuan pertama sebesar $38,93 \%$ dan aktivitas negatif sebesar $61,07 \%$. Namun, pada pertemuan kedua, aktivitas positif siswa meningkat menjadi $55,36 \%$ dan aktivitas negatif pada saat pembelajaran berlangsung menurun menjadi $44,64 \%$. Sedangkan pada siklus II pertemuan pertama sebesar $81,43 \%$ dan aktivitas negatif sebesar $18,57 \%$. Namun, pada pertemuan kedua, aktivitas positif siswa meningkat menjadi $94,29 \%$ dan aktivitas negatif pada saat pembelajaran berlangsung menurun menjadi 5,71\%. Pembelajaran Matematika dengan menggunakan metode learning partner dapat meningkatkan kemampuan perhitungan pecahan siswa kelas V SDN 46 Lela Kota Bima. Hal ini ditunjukkan dengan terjadinya peningkatan skor rata-rata hasil belajar matematika materi perhitungan pecahan menggunakan metode learning patners dari siklus I yakni 58.57 kemudian meningkat sangat signifikan pada siklus II yakni menjadi 85,71. Sedangkan pencapaian ketuntasan belajar pada siklus I sebesar $17,9 \%$ dan meningkat pada siklus II yakni sebesar $92,9 \%$.

\section{DAFTAR PUSTAKA}

Hajar, Andi (2020). "Penerapan Metode Pembelajaran Learning Partner dalam Meningkatkan Hasil Belajar Pendidikan Agama Islam", Jurnal DIDAKTIKA, No. 1 Volume IX.

Kusumaningsih, Andri (2015). "Eksperimen Pembelajaran Matematika Melalui Model Pembelajaran Partners In Learning dan Problem Based 
Learning Ditinjau Dari Minat Belajar Siswa Kelas X Semester Genap di SMK Muhammadiyah 1 Sukoharjo Tahun Ajaran 2014/2015". "Skripsi”, Universitas Muhammadiyah, Surakarta.

Selan, Merti dkk. (2018). "Penerapan Model Pembelajaran Bertukar Pasangan Berbantuan Media Kartu Soal Untuk Meningkatkan Keaktifan dan Hasil Belajar Siswa Kelas IV Sekolah Dasar", Jurnal Pendidikan Indonesia, No 2, Volume IV.

Zulva, Rahmi dkk. (2020)."Pengaruh Efektivitas Pembelajaran Bertukar Pasangan Terhadap Peningkatan Hasil Belajar Kognitif IPA-Fisika Peserta Didik". Jurnal JRFES, No. 1, Volume VII.

Yenti. Rosni. (2018). "Penggunaan Model Pembelajaran Kooperatif Teknik Bertukar Pasangan Untuk Meningkatkan Hasil Belajar PKN Siswa Kelas III SD Negeri 110 Pekanbaru", Jurnal Pajar, No 6, Volume II.

Aprianika, Sela dkk. (2019). "Penerapan Model Pembelajaran Mencari Pasangan Dan Bertukar Pasangan Dalam Kelompok Diskusi Terhadap Hasil Belajar Siswa Pada Materi Sistem Koloid Kelas XI IPA MAN 1 Kota Bengkulu", Jurnal Pendidikan dan Ilmu Kimia, No 1, Volume III

Wulandari, Sri dkk. (2010)."Efektivitas Model Bertukar Pasangan Pada Persamaan Dasar Akuntansi Terhadap Hasil Belajar Siswa Di SMA", Jurnal Pendidikan dan Pembelajaran Khatulistiwa, No 3, Volume II

Suyadi (2013). Paduan Penelitian Tindakan Kelas. Yogkakarta: Diva Press,

Sanjaya,Wina. (2010). Strategi \& Model Pembelajaran Berorientasi Standar Proses Pendidikan. Jakarta: Kencana.

Nikmah, Sofiatun. (2018). "Peningkatan Hasil Belajar Matematika Materi Pecahan Sederhana Melalui Media Visual Pada Siswa Kelas III MI Miftahul Ulum Duren Kecamatan Tengaran Kabupaten Semarang Tahun Ajaran 2017/2018". "Skripsi". Institut Agama Islam Negeri, Salatiga.

Dewi, Mitra (2011)."Penerapan Model Pembelajaran Kooperatif Teknik Bertukar Pasangan Untuk Meningkatkan Kemampuan Pemecahan Masalah Matematika Siswa Kelas VIII Mts Sawah Kecamatan Kampar Utara Kabupaten Kampar". "Skripsi”, Universitas Islam Negeri Sultan Syarif Kasim, Riau Pekanbaru.

Septianti, Dania Rizky. (2016). "Peningkatan Prestasi Belajar Matematika Materi Pecahan Melalui Pendekatan Realistic Mathematic Education (RME) Pada Kelas III MI Al Huda Munggangsari Kecamatan Kaliangkrik Kabupaten Magelang Tahun Ajaran 2015/2016. "Skripsi", Institut Agama Islam Negeri, Salatiga. 